\section{Serial case reports: Pregnancy with Lucio's phenomenon of leprosy in dr. Soetomo hospital, Surabaya}

\author{
Nareswari I. Cininta, M.I.A. Akbar, \\ Rozi A. Aryananda, \\ Khanisyah E. Gumilar, \\ Manggala Pascawardhana, \\ Budi Wicaksono, Ernawati, \\ Agus Sulistyono, Aditiawarman, \\ Hermanto T. Joewono, M.N. Abdullah, \\ Erry G. Dachlan \\ Maternal Fetal Medicine Division, \\ Obstetrics \& Gynecologic Department, \\ Faculty of Medicine, Universitas \\ Airlangga, Dr. Soetomo General \\ Hospital, Surabaya, East Java, \\ Indonesia
}

\begin{abstract}
Leprosy is a complex disease which will affect in many aspects of the patient. In dr. Soetomo hospital, there were two cases of pregnancy with leprosy and Lucio's phenomenon from 2014 until 2018. Both had been receiving multidrug therapy (MDT) before pregnancy but stopped due to lack of compliance. First case was resulted with term. Second case was admitted with worse condition than the first case, fetal growth restriction and ended with preterm delivery probably because the severity of the case. Lucio's phenomenon incidence is increased in pregnancy due to immunodeficient condition. This serial case report shows that the initial diagnosis and optimum treatment of leprosy is very important especially in women of child-bearing age.
\end{abstract}

\section{Introduction}

The global trend of new cases of leprosy detected shows gradual decline from 265,661 in 2006 to 210,758 in $2015 .{ }^{1}$ By 2015 , Indonesia is still the third country with the highest new case of leprosy (3\%) after India (60\%) and Brazil (13\%). On 2000 , leprosy has been declared eradicated and for twelve years the prevalence was 8$10 / 100,000$ people (the target is $<10 / 100,000$ or $<1 / 10,000)$ On 2015 the prevalence was $0.79 / 10,000$, with a slight increase on $20160.80 / 10,000^{2,3}$ The province with highest prevalence is on West Papua with $15.07 / 10,000$ and the case detection rate of $94.36 / 100,000$. Leprosy has a bimodal age distribution, with one peak between 10 and 15 years of age and a second peak between 30 and 60 years of age. Lucio's phenomenon is a diffuse nodular form of lepromatous leprosy and was first described in 1948 by Latapi and Chavez. In dr. Soetomo hospital, there were two cases of pregnancy with leprosy and Lucio's phenomenon from 2014 until 2018. In this, case reports we aim to discuss the management of pregnancy with leprosy, the effect of the disease to the pregnancy and the physiological changes in pregnancy effect on the disease ${ }^{1,2,3,4}$

\section{Case Report}

\section{Case \#1}

A 29-year-old primigravida, 29/30 weeks of pregnancy, from Pare, Kediri, East Java, Indonesia was admitted to the emergency room of dermatovenereology department with the suspicion of Steven Johnson's syndrome and consulted to OB/GYN department due to her pregnancy. Her initial complaint was three years before pregnancy with the thickening of the earlobes and loss of eyebrows, she claimed to receive medication from the dermatovenereologist but ceasing her treatment due to unknown reason. She only did antenatal care three times at the midwife and was categorized as high-risk pregnancy due to leprosy. On the first trimester she complained painful scarlet spots with darkening and ulcers on her hands and legs. She was given medication at Pare hospital but her condition was not improving. Three days before admission, the spots were progressing, she was given antibiotic by a general physician but she experienced fever. She was admitted to Pare hospital for two days and referred to dr. Soetomo hospital, Surabaya, due to her deteriorating condition. She was presented with good vital sign, no fever, underweight (body mass index/BMI=17.7), with her fundal height 19 $\mathrm{cm}$, fetal heart rate of 152 beats per minute, no signs of labour. Her laboratory result was anemic with hemoglobin level $8.9 \mathrm{~g} / \mathrm{dl}$ on the first day of admission and dropped down until $6 \mathrm{~g} / \mathrm{dl}$ on the third day of admission. Aside from anemia, she also suffered from hypoalbuminemia with the declining trend from $2.6 \mathrm{~g} \%$ to $1.9 \mathrm{~g} \%$ The sonography examination at the maternal fetal medicine division appeared with the exceptional result, no signs of fetal growth rate restriction, good amount of amniotic fluid and no markers of major congenital anomaly. The Doppler velocimetry examination of umbilical artery showed normal waveform and values.

The cardinal signs of leprosy, such as hypopigmentation or erythematous patches
Correspondence: Nareswari Cininta Obstetrics \& Gynecologic Department Dr Soetomo general hospital, Jl. Prof. dr. Moestopo 6-8, Surabaya, East Java, Indonesia, 60285. Phone: +6281233721937 .

E-mail: nareswari cininta@yahoo.com

Key words: leprosy, Mycobacterium leprae, pregnancy, parturition

Contributions: The authors contributed equally.

Conflict of interests: The authors declare no potential conflict of interest.

Funding: None

Received for publication: 1 February 2019. Accepted for publication: 25 February 2019.

This work is licensed under a Creative Commons Attribution-NonCommercial 4.0 International License (CC BY-NC 4.0).

(C) Copyright N.I. Cininta et al., 2019

Licensee PAGEPress, Italy

Dermatology Reports 2019; 11(s1):8097

doi:10.4081/dr.2019.8097

of the skin and sensory loss were not present. From facial region there was madarosis, facies leonina, earlobes thickening. From upper and lower extremities, there were multiple erythematous macula with clear and several unclear boundaries, bullous lesion, erosion and crustae (Figure 1) Slit-skin smear from earlobes showed bacterial index (BI) $6+$ and morphological index (MI) 7\%. A skin biopsy from the leg's ulcer showed atrophic epidermis with Gentz zone, foam cells with some lymphocyte cells, vasculitis with endothelium occlusion of thrombus on the dermis. There was lymphocyte infiltration at the blood vessels. Acid-fast bacili were positive in subcutaneous fat and endothelium of blood vessels. These findings suggested Lucio's phenomenon (Table 1).

She received blood and albumin transfusion, WHO-MDT Multi Bacillary (MB) regimen, antibiotic with Claritromycin and dexamethasone administration $0.5 \mathrm{mg}$, three times daily for two weeks and substituted with methylprednisolone tablets, 16 $\mathrm{mg}$, twice daily, tapering off for one month, along with $1,000 \mathrm{mcg}$ of folic acid, once daily. Samples were collected from skin lesion, amniotic fluid to detect M. leprae DNA using Polymerase Chain Reaction (PCR) method and on delivery samples from umbilical cord blood, placenta membrane were taken for serological examination of phenolic glycolipid-1 (PGL-1) using Enzyme Linked Immunosorbent Assay (ELISA). PCR examination result were: 1 : 
taken from skin lesion, positive result; 2 : taken from amniotic fluid, positive result; 3 : taken from placenta membrane, negative result; 4: taken from umbilical cord blood, negative result.

During her admission, she suffered skin loss at the digits of her lower extremities and many lesions at the inguinal area which cause difficulty on performing lithotomy position for delivery. Thus, the team decided to perform cesarean delivery and insertion of contraceptive intrauterine device on $39 / 40$ weeks of pregnancy. Her baby was born male, weighing $2650 \mathrm{~g}, 48 \mathrm{~cm}$, Apgar score $8-9$, no signs of growth restriction from the Ballard's score (appropriate with $38 / 39$ weeks of pregnancy) and Lubchenko's score of p10-25. There were no signs of congenital leprosy at the baby.

\section{Case \#2}

A 21-year-old primigravida, 31/32 weeks of pregnancy, from Sampang, East Java, Indonesia was admitted to the emergency room of dermatovenereology department with the Lucio's phenomenon and consulted to $\mathrm{OB} / \mathrm{GYN}$ department due to her pregnancy. Her mother suffered leprosy for ten years ago but she refused medication, while the patient initial complaint was four years before pregnancy with hypopigmentation macula at the feet. At the end of 2017 the lesions worsened and she received MDT from Sampang primary health centre only to take it for one month due to diarrhea. She only did twice antenatal care at the midwife and was categorized as highrisk pregnancy due to leprosy. Since third until fifth months of pregnancy the painful ulcers appeared and she was admitted to Sampang general hospital for three days before referred to dr. Soetomo hospital.

She was presented with good vital sign, no fever, (body mass index/BMI= 17.8) with her fundal height $21 \mathrm{~cm}$, fetal heart rate of 160 beats per minute, no signs of labour. Her laboratory result was pancytopenia with hemoglobin level $9.3 \mathrm{~g} / \mathrm{dl}$, leucocyte level of 2,780 and thrombocyte level of 65,000 . She also suffered from hypoalbuminemia with $1.6 \mathrm{~g} \%$

The sonography examination at the emergency delivery room appeared with suspicion of fetal growth rate restriction with overall biometry appropriate with 29/30 weeks, low amount of amniotic fluid (amniotic fluid index $=3.6$ ) which causes the exploration for markers of major congenital anomaly was not performed due to technical difficulty. The Doppler velocimetry was not performed due to limitation of the sonography device.

From facial region there was madarosis, facies leonina, earlobes thickening (Figure
2) From upper and lower extremities, there were multiple erythematous macula with clear and several unclear boundaries, bullous lesion, erosion and crustae. The dermatovenereology department planned for biopsy of the lesion, serology and PCR examination from skin biopsy and blood. She received antibiotic with Cloxacillin $500 \mathrm{mg}$ three times daily and dexamethasone administration $0.5 \mathrm{mg}$, once daily for two days and tapering off, along with $1,000 \mathrm{mcg}$ of folic acid, once daily. For the exploration of the pancytopenia, we planned for blood smear examination, serum ferritin level, serum iron level, total iron binding capacity level, ANA test, C3, C4.

Due to the condition of the fetus with signs of growth restriction, we planned to do conservative treatment for maternal saving and have multidisciplinary discussion for the further plan of this case. On the third day her admission before case discussion, she entered labour and resulted in preterm delivery. Her baby was born male, weighing 1200 g (appropriate with 29/30 weeks of pregnancy), $40 \mathrm{~cm}$, Apgar score 1-1-0 There was no sign of congenital leprosy at the baby. The patient received MDT after deliv-

Table 1. ELISA examination result of the first case.

\begin{tabular}{lcccc} 
Subject & \multicolumn{2}{c}{ ELISA anti PGL-1 } & \multicolumn{2}{c}{ Cutt-off } \\
& $\operatorname{Ig} M(\mathrm{u} / \mathrm{mL})$ & $\operatorname{IgG}(\mathrm{u} / \mathrm{mL})$ & $\operatorname{IgM}(\mathrm{u} / \mathrm{mL})$ & $\operatorname{IgG}(\mathrm{u} / \mathrm{mL})$ \\
Patient & 4.854 & 1.061 & 605 & 630 \\
Umbilical Cord & & & & \\
\hline Blood & 0 & 516 & & \\
\hline
\end{tabular}
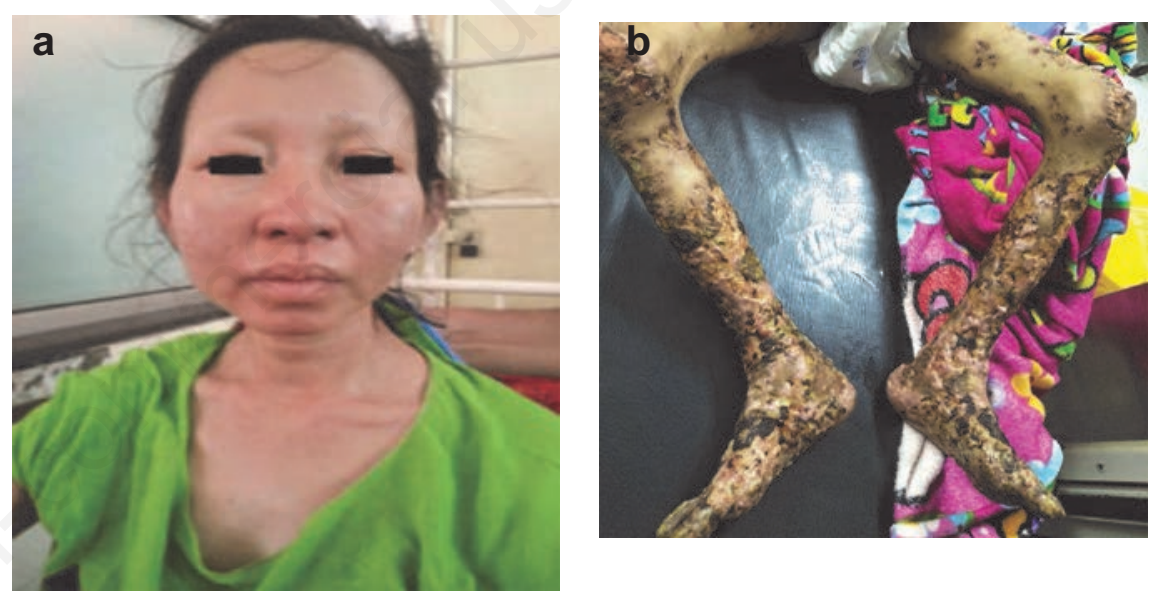

Figure 1. (a) Eyebrow loss; (b) Hyperpigmented macula and plaques at both extremities.
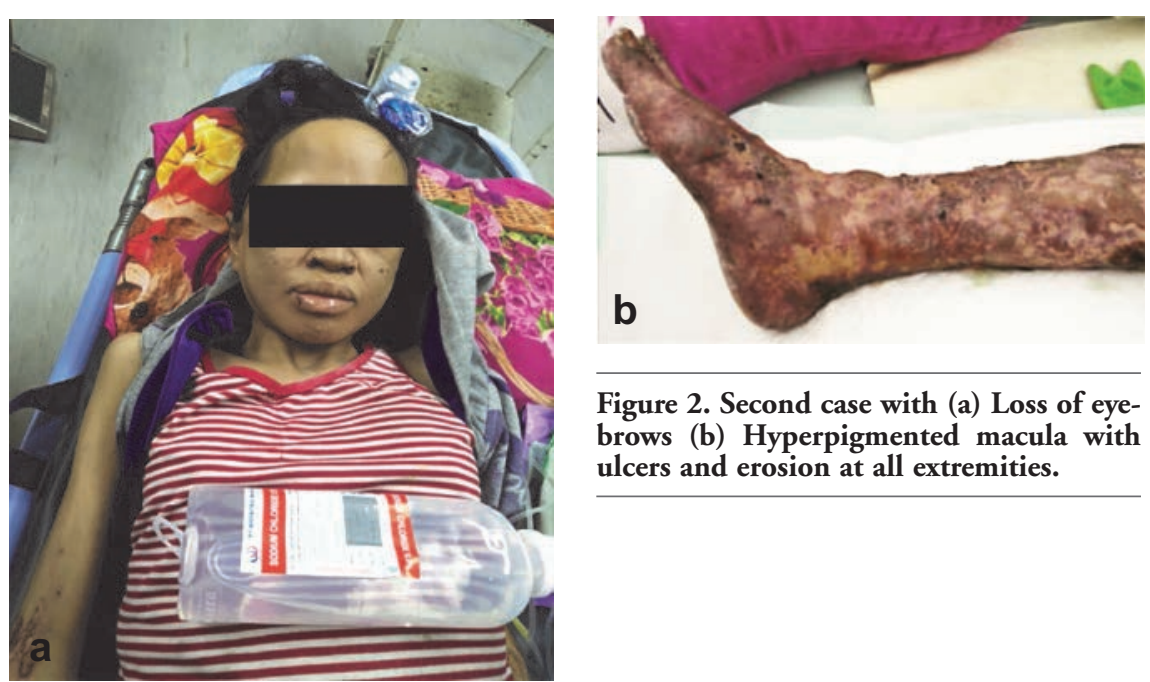

Figure 2. Second case with (a) Loss of eyebrows (b) Hyperpigmented macula with ulcers and erosion at all extremities. 
ery and there are no signs of complication from the gynecologic organs. We advised her to take optimum treatment for leprosy until relieved before attempting another pregnancy.

\section{Discussion}

The US NHDP estimates that more than $95 \%$ of individuals are not susceptible to leprosy, even after significant exposure. Individuals who develop leprosy demonstrate an impaired cell-mediated immune response to the $M$. leprae bacillus and this results in widespread systemic disease. The underreporting of leprosy cases particularly in women is affected by low education level, low economic status and other cultural factors. Pregnancy causes relative decrease of cellular immunity which allows $M$. leprae to proliferate and the incidence of relapse after treatment may precipitate the first symptoms of leprosy, neuritis, and the erythema nodosum leprosum The infant has high risk of contracting leprosy from skin-to-skin contact or droplet transmission from the mother, especially if she does not get treatment ${ }^{4,5}$ Prakoeswa et al reported the possi- bility of placenta as protective barrier towards vertical transmission of M. leprae. PGL-1 is a specific antigen to the M.leparae bacillus and to be shown higher in multibacillary cases than paucibacillary cases. PGL-1 has role in demyelination of Schwann cells. On examination of $\operatorname{IgG} / \operatorname{IgM}$ anti-PGL-1 titers were high at the mother and low at the umbilical cord blood. This proved that placenta provide adequate innate defense against pathogens. MDT should also be continued during pregnancy because of the safety for maternal and fetal side. The US NHDP advises females of childbearing potential to avoid pregnancy until treatment is completed 4,6

\section{Conclusions}

The cellular immunity changes during pregnancy contributed to leprosy progression especially in untreated cases. $20-30 \%$ of pregnant women has first symptoms of leprosy during pregnancy or immediately after and Lucio's phenomenon are more commonly seen due to the immunodeficient state of pregnancy. It is important to detect and treat leprosy before pregnancy to avoid maternal and fetal complications during pregnancy.

\section{References}

1. WHO. Global leprosy situation. Weekly Epidemiological Record, 2016; 91(35), 405-420

2. Kementrian Kesehatan Republik Indonesia, 2012, Pedoman Nasional Program Pengendalian Penyakit Kusta. Jakarta. Direktorat Jenderal Pengendalian Penyakit dan Penyehatan Lingkungan

3. Kementrian Kesehatan Republik Indonesia, 2017, Profil Kesehatan Indonesia Tahun 2016. Jakarta . Kementrian Kesehatan RI

4. Tyring SK, Lupi O, Hengge UR. Tropical Dermatology E-Book: Elsevier Health Sciences; 2016.

5. Lockwood DN, Sinha HH. Pregnancy and leprosy: a comprehensive literature review. Int J Lepr Other Mycobact Dis. 1999;67:6-12

6. Prakoeswa CRS, Herwanto N, Agusni RI, Natalya FR, Listiawan MY, Adriaty $\mathrm{D}$, et al. Lucio phenomenon of leprosy LL type on pregnancy: A Rare Case. Leprosy review. 2016;87(4). 